\title{
Groundwater Studies: Principal Aquifer Surveys
}

\section{The NAWOA Program}

In 1991, the U.S. Congress established the National Water-Quality Assessment (NAWQA) program within the U.S. Geological Survey (USGS) to develop nationally consistent long-term datasets and provide information about the quality of the Nation's streams and groundwater. The USGS uses objective and reliable data, water-quality models, and systematic scientific studies to assess current water-quality conditions, to identify changes in water quality over time, and to determine how natural factors and human activities affect the quality of streams and groundwater. NAWQA is the only non-regulatory Federal program to perform these types of studies; participation is voluntary.

In the third decade (Cycle 3 ) of the NAWQA program (2013-2023), the USGS will evaluate the quality and availability of groundwater for drinking supply, improve our understanding of where and why water quality is degraded, and assess how groundwater quality could respond to changes in climate and land use. These goals will be addressed through the implementation of a new monitoring component in Cycle 3: Principal Aquifer Surveys.

\section{In partnership with the NAWQA} Program, we collected a significant amount of groundwater-quality data that neither agency could have obtained individually. The data provide an important snapshot of the overall health of groundwater -the region's primary source of drinking water. The information generated through this partnership will help our region formulate more effective groundwater management strategies in the future.

\section{What will Participants Gain from the NAWOA Principal Aquifer Survey?}

The survey will provide water utilities and resource managers with information about the following:

- Regulated and unregulated constituents from natural or human sources.

- Pesticides, pharmaceuticals, hormones, and other constituents of concern for human health.

- Baseline groundwater quality for comparison with future conditions.

- Regional and national statistics on water quality, as context for individual wells.

- A comparison of water quality in the shallow and deep parts of aquifer systems.

- Environmental tracers that can be used to understand sources and sustainability of groundwater supplies.

- Improving understanding of local, regional, and national hydrogeology.

Sampling a public-supply well in San Bruno, CA. Photograph by Cathy Munday, U.S. Geological Survey

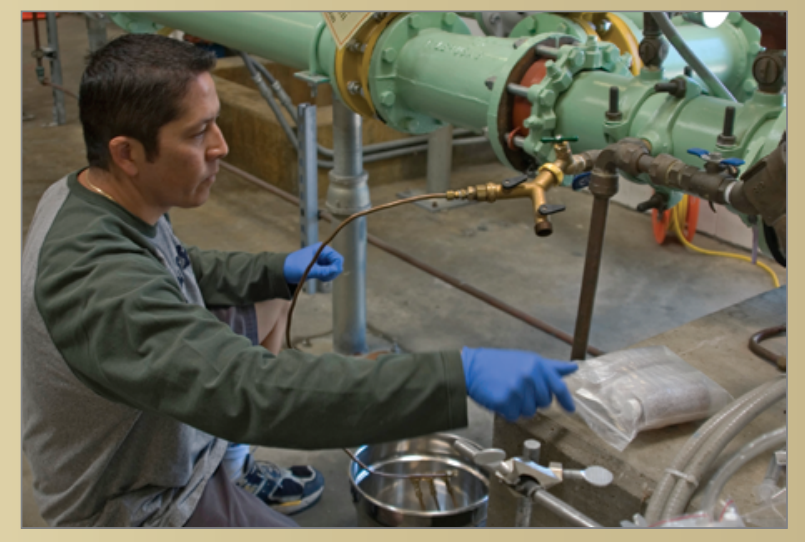

\section{NAW0A Principal Aquifer Survey}

Principal aquifers are regionally extensive aquifers that can be used as a source of drinking water. Principal Aquifer Surveys (PAS) will assess the quality of groundwater used for public supply and will use newly collected data along with existing water-quality data.

Previously, the NAWQA program focused on the quality of groundwater in shallow monitoring wells and in domestic-supply wells and evaluated the distribution of contaminants in shallow groundwater (fig. 1). The PAS studies will focus on public-supply wells that tap deeper groundwater than typical domestic-supply wells. The PAS studies will be carried out over entire principal aquifers, rather than targeting smaller areas. The USGS will use the PAS data to develop contaminant distribution maps for deeper groundwater, thus completing a three-dimensional picture of groundwater quality and complementing previous NAWQA studies.

\section{NAWOA Principal Aquifer Survey Study Design}

The USGS has identified 68 principal aquifers across the Nation. Groundwater pumped from these aquifers provides 45 percent of the Nation's drinking-water supply. During these Cycle 3 studies, NAWQA will sample groundwater used for public supply in 20 of the 68 principal aquifers (fig. 2). These 20 principal aquifers account for 76 percent of the Nation's groundwater pumped for public supply and 85 percent of the groundwater pumped for domestic supply.

Samples collected by the USGS for the PAS assessments will be analyzed for a large suite of regulated and unregulated constituents. The methods used by the NAWQA program will include 
Figure 1. Statistical model for groundwater from domestic wells sampled during 1991-2003 (Nolan and Hitt, 2006). $\leq$, less than or equal to; >, greater than

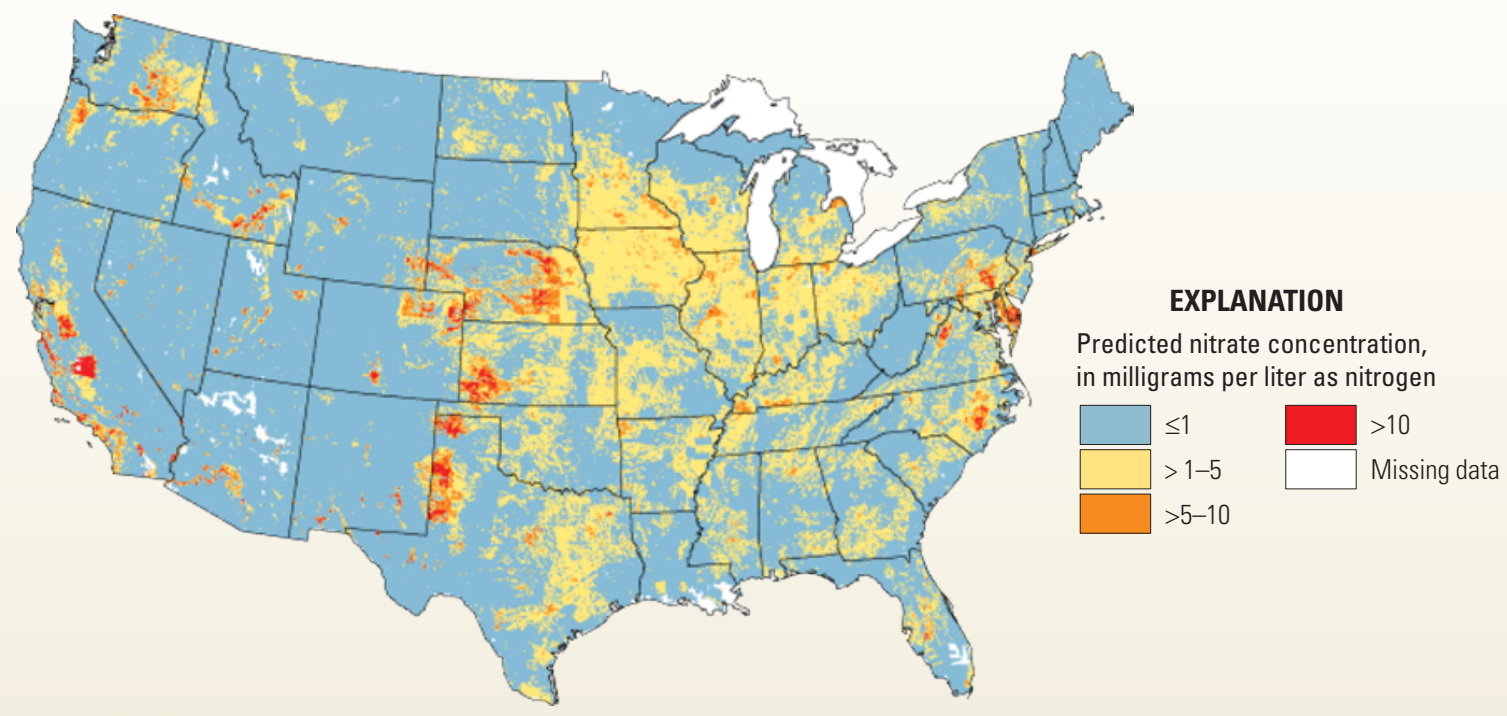

Figure 2. Principal aquifers in the United States selected for monitoring in the Principal Aquifer Surveys (PAS) and for additional intensive study (which are identified), as well as important principal aquifer systems not included in this Cycle 3 assessment.

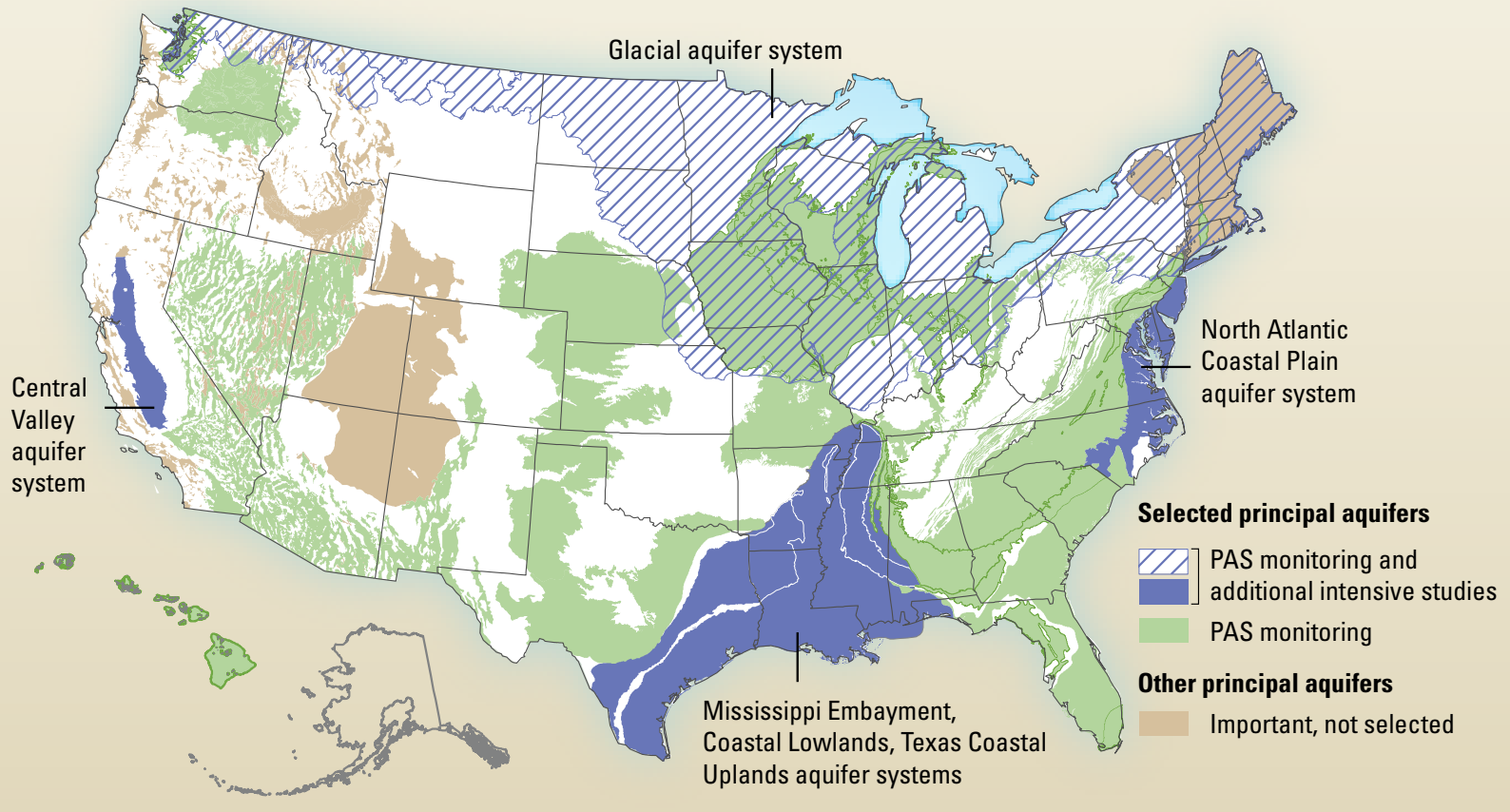

more constituents, detected at lower concentrations, than other programs. These constituents include trace elements, radioactivity, nutrients, salinity, pesticides, and volatile organic compounds. The NAWQA program will also include sampling for pharmaceuticals, hormones, and microbial indicators. The PAS studies are focused on untreated groundwater collected from public-supply wells, rather than treated drinking water delivered to consumers. The PAS studies are designed to assess groundwater quality at the regional scale and to complement regulatory monitoring programs. Findings will assist water-utility managers and regulators in making decisions about future monitoring needs and drinkingwater issues.

\section{Reporting Results}

The NAWQA PAS will provide new water-quality data and assessment of water resources to participants. Results of the sampling will be provided to well owners at no cost. Well-owner information will be kept confidential. Data summaries and interpretive reports will be made publically available on NAWQA websites and through USGS databases and publications.

\section{References}

Nolan, B.T., and Hitt, K.J., 2006, Vulnerability of shallow groundwater and drinking-water wells to nitrate in the United States: Environmental Science and Technology, v. 40, no. 24, p. 7834-7840.
By Karen R. Burow and Kenneth Belitz

For more information http://water.usgs.gov/nawqa/

NAWQA reports and data can be obtained here:

NAWQA Groundwater Project Chief U.S. Geological Survey

12201 Sunrise Valley Drive, MS 413

Reston, VA 20192-0002

Telephone: (703) 648-5716 